\title{
Fires AND Funds: A Young SCIENTIST'S PERSPECTIVE
}

\author{
By C.J. Beegle
}

$\mathbf{T}$ HOSE ATTENDING the policy sessions at the TOS Hawaii meeting came away with a strong reminder of the real source of research monies-the American taxpayer. As scientists, one of our greatest responsibilities is to help people make informed decisions based on what science indicates are the consequences of particular actions or inactions. We live in an era of metaphorical fires, such as global warming, fisheries collapse, and ozone depletion. We must educate the population that the wisdom of preventing fires is more valuable than the glory of stamping out fires. We must also educate the public to see through wildfires created by sensationalism rather than scientific controversy, such as natural disaster predictions made by unqualified individuals.

We heard some of the problems with our university based research system: there are not enough tenure positions for all the talented new Ph.D.s; the prospect of funding increases is bleak: and community service and teaching are not highly valued in tenure decisions. The challenge to the scientific community is to understand the importance of careers outside academia where scientists can make important contributions to science in forming public policy and societal priorities along- side research. Another challenge is to create new sources for "hard-money" teaching positions. For example, state and industrial funds could be used to support a chair for a professor who spends one day each week during teaching quarters working with local K-12 schools rather than working at the university.

Science is governed by great conservation principles, but scientists over the last few decades have lost track of the one principle vital to their existence: if the scientific community wants the American people to make the long-term investment in basic research. then we as scientists must make the longterm investment in educating the people to take part in a more scientifically literate society. We must take the time to explain to the people and elected officials what we do. why we do it, and how understanding our natural world can better all our lives economically and environmentally. This will mean rebalancing our established system to value more highly those individuals gifted in public outreach or teaching. Individual scientists should be valued for exemplary work in their own combination of time spent in research, teaching, and public outreach. Within oceanography, we are in one of the best positions to succeed within this new climate. 